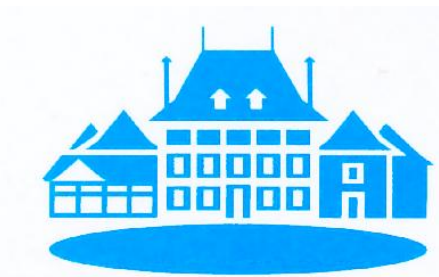

STUDY CENTER

GERZENSEE

\title{
Words, deeds, and outcomes: A survey on the growth effects of exchange rate regimes
}

Philipp Harms and Marco Kretschmann

Working Paper 07.03

This discussion paper series represents research work-in-progress and is distributed with the intention to foster discussion. The views herein solely represent those of the authors. No research paper in this series implies agreement by the Study Center Gerzensee and the Swiss National Bank, nor does it imply the policy views, nor potential policy of those institutions. 


\title{
Words, deeds, and outcomes: A survey on the growth effects of exchange rate regimes
}

\author{
Philipp Harms (RWTH Aachen University and Study Center Gerzensee) \\ and Marco Kretschmann (RWTH Aachen) ${ }^{1}$
}

March 2007

\begin{abstract}
:
Recent studies on the growth effects of exchange rate regimes offer a wide range of different, sometimes contradictory results. In this paper, we systematically compare three prominent contributions in this field. Using a common data set, a common specification, and common estimation methods, we argue that the contradictory findings can be explained by the fact that these studies use regime classifications which reflect fundamentally different aspects of exchange rate policy.
\end{abstract}

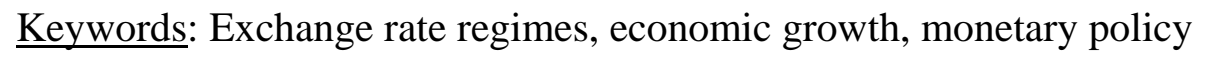

JEL classification codes: E 52, F31, F41, F43

\footnotetext{
${ }^{1}$ Philipp Harms, RWTH Aachen University, Faculty of Business and Economics, Templergraben 64/III, D52062 Aachen, Tel. +49(0)241 80-96203. Email: harms@rwth-aachen.de. Marco Kretschmann , RWTH Aachen, Faculty of Business and Economics, Templergraben 64/III, D-52062 Aachen, Tel. +49(0)241 80-96214. Email: marco.kretschmann@rwth-aachen.de. We would like to thank Philippe Bacchetta, Herbert Brücker and Carsten Hefeker for valuable comments. Andreas Gerads, Juliane Kohnert, Timur Pasch, Nataliya Vasileva and Senem Yaman provided excellent research assistance.
} 


\section{Introduction}

The relative advantages of different exchange rate regimes are subject to ongoing discussions among policymakers and academics. It is thus not surprising that considerable attention is devoted to the question whether there is an empirical relationship between a country's exchange rate regime and important macroeconomic targets: does a fixed exchange rate regime enhance price stability? Does the flexibility associated with floating exchange rates dampen the effects of real shocks and thus lower macroeconomic volatility? And which exchange rate regime is correlated with higher growth rates of real per-capita income? ${ }^{1}$ While these questions have been raised repeatedly throughout the post-war era (Mussa 1986, Baxter and Stockman 1989), the more recent past has seen a veritable boom of studies that investigate the empirical relationship between countries' exchange rate regimes and their macroeconomic performance. This collective research effort is lead by the comprehensive monograph of Gosh, Gulde and Wolf (2002) as well as the widely-quoted papers by LevyYeyati and Sturzenegger (2003) and Rogoff, Husain, Mody, Brooks and Oomes (2003). ${ }^{2}$

There are different explanations for the renewed interest in the macroeconomic effects of exchange rate regimes: first, recent historical experience - the spectacular sucess of exchange-rate based stabilization programs, the introduction of the Euro, but also the collapse of fixed exchange rate regimes in several emerging markets - has spurred the discussion about the superiority of certain exchange rate arrangements. Second, with 30 years having passed since the breakdown of the Bretton Woods system, there is a sufficient variety of regime choices and macroeconomic experiences to reasonably assess this question. Finally, and perhaps most importantly, researchers can now use several new data sets which allow to distinguish between countries' de-jure exchange rate regimes and the exchange rate policy that was actually implemented by monetary authorities. Such a distinction is important since, on the one hand, many countries tolerated - and still tolerate - the existence of parallel foreign exchange markets, and in these countries the stability of the official exchange rate often conveys a wrong impression about the volatility of the "relevant” (parallel) exchange rate. On the other hand, some countries' currencies are much less volatile than would be justified by the official exchange rate regime - a discrepancy for which Calvo and Reinhart

\footnotetext{
${ }^{1}$ A discussion of the theoretical arguments in favor of pegs and floats would go beyond the scope of our investigation. Concise presentations of those arguments are offered by Gosh et al. (2002) and Rogoff et al. (2003).

${ }^{2}$ A slightly modified version of Rogoff et al. (2003) was published in the Journal of Monetary Economics (Husain et al., 2005). In what follows, we refer to the longer IMF Working-Paper. A twin version of LevyYeyati und Sturzenegger (2003) appeared in the European Economic Review ( Levy-Yeyati and Sturzenegger, 2005).
} 
(2002) have coined the term "fear of floating". The possibility to distinguish between a country's officially announced regime and its implemented policy has certainly contributed to the recent popularity of this research topic.

Those who expect the recent literature to deliver a quick and definite answer on the superiority of certain exchange rate regimes, are, however, likely to be disappointed: the different studies offer a variety of contradictory, sometimes mutually exclusive results, and only some aspects - e.g. the positive effect of fixed exchange rate regimes on price stability meet broad empirical support. The differences between the individual results on the relationship between exchange rate regimes and economic growth are particularly striking: Gosh, Gulde and Wolf (2002, in what follows denoted by GGW) find a slightly positive, but not very robust effect of fixed exchange rates. Conversely, Levy-Yeyati and Sturzenegger (2003, in what follows: LYS) present evidence that flexible exchange rates are associated with higher growth rates, especially in non-industrial countries. Rogoff et al. (2003, in what follows: RHMBO) also find a significantly positive effect of flexible exchange rates, but only for rich ("advanced") economies. Hence, there is a confusing plethora of results and conclusions, and the observer is left with the question which of these findings - if any - he is to trust.

The aim of our study is to shed some light on the relationship between exchange rate regimes and economic growth by systematically comparing the three studies mentioned above. Such a comparison promises various insights: first, it makes it easier to assess which results are driven by the choice of a particular sample, model specification, or estimation method. Second, and more importantly, it allows to interpret the economic content of the different results: the individual studies are using classification schemes which reflect fundamentally different aspects of exchange rate policy: the classification of GGW is based on countries' official announcements about their exchange rate regimes. Conversely, LYS classify "de-facto" regimes by considering the observed volatility of the (official) exchange rate and the fluctuations of countries' foreign exchange reserves. Finally, RHMBO use the “natural classification” of Reinhart und Rogoff (2004, in what follows: RR), which focuses on the volatility of the relevant (possibly parallel) exchange rate. These fundamental differences between the three classification methods allow for the possibility that all results are, in some well-defined way, „correct“: it is conceivable that the effects of an announced peg differ from the effects of active exchange rate stabilization. And the impact of a stable exchange rate may crucially depend on whether this stability is associated with fluctuations in a country's stock of foreign reserves or not. The seemingly contradictory results would thus 
indicate that different aspects of "exchange rate stability" differ in their effects on growth. However, to arrive at such a conclusion, we first have to put the individual studies on an equal footing.

In the rest of the paper, we proceed as follows: Section 2 briefly reviews the principles underlying the different classification methods. In Section 3, we summarize the results of the existing literature and describe the problems with interpreting these findings. Section 4 explains our econometric model and the data we use. Section 5 presents and interprets our own empirical results, and Section 6 concludes.

\section{Identifying exchange rate regimes: a brief review}

\subsection{De-jure and de-facto classifications}

In this section, we briefly recapitulate the approaches of GGW, LYS and RR to identify the exchange rate regime prevailing in a given country at a given point in time. For the GGW classification, this is fairly simple: In their study, these authors adopt the information given by countries' monetary authorities, as published in the IMF's Annual Report on Exchange Arrangements and Exchange Restrictions. ${ }^{3}$ Hence, they use a pure de-jure classification which reflects the officially announced strategy of countries’ monetary authorities.

The approaches of LYS and RR are more sophisticated. The goal of these classifications is to go beyond official announcements and to identify countries' de-facto regimes, based on the properties of observed time series. In what follows, we briefly describe both approaches.

\subsection{The classification of Levy-Yeyati and Sturzenegger (2003)}

LYS identify a country's de-facto exchange rate regime by considering the following variables: the volatility of the bilateral nominal exchange rate with respect to some anchor currency $\left(\sigma_{e}\right)^{4}$, the volatility of exchange rate changes $\left(\sigma_{\Delta e}\right)$, and the volatility of foreign reserves $\left(\sigma_{r}\right)$. Having computed these statistics, all country-year observations are assigned to one of four regimes: „Flexible“, „Dirty Float“, „Crawling Peg“ or „Fix“. In classifying observations, the authors are led by the following considerations: with a flexible exchange

\footnotetext{
${ }^{3}$ GGW also develop a „consensus classification“, which eliminates observations for which the volatility of the exchange rate is not compatible with the official announcement (Gosh et al., 2002:46 ff.). To highlight the difference between de-jure and de-facto regimes, we neglect the „consensus classification“.

${ }^{4}$ Both LYS and RR base their classifications on bilateral exchange rates. While Dubas et al. (2005) point out that the focus on bilateral exchange rates may exaggerate exchange rate fluctuations, the use of effective exchange rates meets severe data limits.
} 
rate, $\sigma_{e}$ and $\sigma_{\Delta e}$ should be rather high. Conversely, $\sigma_{r}$ should be low since there is no need for central bank intervention in the presence of a floating exchange rate. By contrast, frequent interventions in case of a fixed exchange rate regime should be reflected by a high value of $\sigma_{r}$, while $\sigma_{e}$ and $\sigma_{\Delta e}$ should be low. The intermediate solutions (Dirty Float und Crawling Peg) should be characterized by both high exchange rate volatility and large fluctuations in reserves. If all three variables are low, an observation is categorized as "inconclusive”.

To identify the de-facto exchange rate regime prevailing in a country during a given year, LYS use K-Means cluster analysis, whose algorithm is based on the "nearest centroid sorting“- approach. They first define the number of „clusters“ - i.e. the number of different exchange rate regimes. Based on this decision, observations in the $\left(\sigma_{e}, \sigma_{\Delta e}, \sigma_{r}\right)$-space are assigned to one of those clusters, following the objective to minimize the distance between observations and the clusters' centers. These centers, in turn, are identified through subsequent iterations.

\subsection{The „Natural Classification“ of Reinhart and Rogoff (2004)}

To classify exchange rate regimes, RR use comprehensive country chronologies which offer information on the prevailing official exchange rate regime, the relevant anchor currency, and on important economic events. In addition, they analyze the statistical properties of the official and (if available) parallel exchange rate. RR justify their focus on parallel market data by pointing out the systematic deviations of parallel market rates from official rates. Moreover, they argue that, in many countries, parallel rates are more relevant for economic transactions than official rates. In a first step, all country-years that are characterized by an annual inflation rate above 40 percent are assigned to a special category labelled „freely falling“. RR justify this approach by arguing that countries with extremely high inflation rates are hit by macroeconomic shocks that should not be associated with a particular exchange rate regime (Reinhart and Rogoff, 2004:16). If the inflation rate is below 40 percent, the de-facto exchange rate regime depends on the volatility of the "relevant" exchange rate, which may be the rate observed on the parallel exchange market.

\subsection{Reserves volatility and the de-facto classifications}

It is important to note that the "natural classification" of RR does not provide any information about the sources of exchange rate stability: while LYS identify a de-facto peg if (and only if) a low volatility of the official exchange rate is combined with strong fluctuations in foreign reserves, the RR pegs do not reveal whether exchange rate stability stems from active central 
bank intervention or just reflects a stable macroeconomic environment. This difference will be very important when it comes to interpreting our empirical results.

To assess whether differences between the two classifications actually stem from the consideration (LYS) or neglect (RR) of reserves volatility or simply from the different methodologies applied (cluster analysis vs. the definition of critical band widths) we computed the average annual reserves volatility associated with LYS pegs and RR pegs, respectively. As expected, average reserves volatility for LYS pegs is 13 percent higher than for RR pegs. Moreover, we ran probit regressions to explore whether, for a given variability of the nominal exchange rate, reserves volatility significantly raises the likelihood to have a country-year classified as a peg. We found that this is indeed the case for LYS pegs. Conversely, reserves volatility has no significant impact on the likelihood that a country-year is classified as a peg à la RR. ${ }^{5}$ These findings confirm our notion that, in addition to stemming from different methodological approaches, the regime classifications reflect different aspects of exchange rate stability - most importantly, the extent to which this stability is associated with active foreign exchange interventions and volatile reserves.

\subsection{Regime-Dummies}

The studies we discuss determine the empirical effect of the exchange rate regime on economic growth by including several „exchange rate regime dummies“ in a standard growth regression. The dummies take the value of one if a specific exchange rate regime prevailed in a given period, and zero otherwise.

Most of our regressions follow the contributions of GGW and LYS in using three regime dummies: fixed exchange rates („,pegs“), intermediate regimes (,intermediates“), and flexible exchange rates („floats“). By contrast, we substantially deviate from the approach of RHMBO in the following respect: as reported above, the RR classification used by RHMBO assigns all those country-years in which the annual inflation rate exceeds 40 percent to a separate „freely falling“-category. ${ }^{6}$ We think that this strategy is problematic: first, the threshold of 40 percent is quite arbitrary. ${ }^{7}$ Second, we argue that this procedure leads to potentially biased results: considering the relationship between exchange rate regimes and price stability, GGW and RHMBO demonstrate that, ceteris paribus, pegs lead to lower inflation rates. Since periods of high inflation are usually associated with low or even negative

\footnotetext{
${ }^{5}$ The results of these regressions are available upon request.

${ }^{6}$ In the sample we use for our estimations, approximately ten percent of all country-years are classified as „freely-falling”.

${ }^{7}$ Referring to Easterly (2001), Reinhart und Rogoff (2004:45) describe the critical value of 40 percent as „,...an important benchmark in the literature on the determinants of growth“.
} 
growth (see, e.g., Bruno and Easterly, 1998), the positive role of fixed exchange rate regimes is likely to be underrated if those episodes are assigned to a separate category. We therefore decided to assign RR's „freely-falling”- observations to one of the three exchange rate regimes. To do this, we used the information given in the RR data appendix and retrieved the regime to which a country-year would have belonged, had it not been classified as "freely falling”. The result is a „modified“ RR-classification ( $\mathrm{RR}^{\mathrm{mod}}$ ), which assigns all observations to a de-facto exchange rate regime, even if the inflation rate exceeds 40 percent. Needless to say that we will later examine the importance of this modification for our results.

In addition to the three-way classification, we also use a four-way classification which splits the group of „intermediate regimes“ into two subgroups: one group of country-years whose exchange rate policy was characterized by extensive, mostly rule-based interventions in foreign exchange markets („limited flexibility“), and another group of country-years, in which interventions were mosty discretionary („managed float“). LYS offer both a three-way and a four-way classification which we could directly retrieve from the authors' homepage. To transform the detailed classifications of GGW and RR into a four-way classification, we followed the approach of Alesina and Wagner (2006). Details are given in the data appendix.

\section{Exchange rate regimes and economic growth: previous results}

As indicated in the introduction, the studies of GGW, LYS and RHMBO present very different results on the relationship between exchange rate regimes and growth. GGW start by finding a slight superiority of pegs, but show that this result is not very robust and eventually conclude: „Overall, and in line with the theoretical literature, the results do not suggest a strong link between the exchange rate regime and real GDP growth“ (Gosh et al., 2002:98). Conversely, LYS summarize their results as follows: „In particular, we found that, for the former [i.e. non-industrial countries], fixed exchange rates are connected with slower growth rates and higher output volatility, an association that proved to be robust to several alternative specifications and checks“ (Levy-Yeyati und Sturzenegger, 2003:1187). RHMBO who use the RR "natural classification" also find a positive influence of exchange rate flexibility on growth, but this effect is limited to the small group of rich ("advanced") countries (Rogoff et al., 2003:44). For the other two country groups - "emerging markets" and “developing countries" - the authors do not find a relationship between exchange rate regimes and growth. Finally, Aghion et al. (2006) demonstrate that the relationship between exchange rate flexibility and productivity growth is nonlinear: in countries with a developed financial sector, 
the positive effects of a flexible exchange rate prevail. Conversely, if firms are subject to credit constraints, exchange rate fluctuations reduce their capability to invest in research and development and thus hamper growth. Since financial sector development is associated with income levels, Aghion (2006) offer a compelling explanation why the growth effects of exchange rate flexibility differ across income groups. Moreover, their result not only holds for the RR "natural classification", but for a host of alternative measures of exchange rate flexibility. However, the relevant coefficients switch signs if the original LYS-classification is used.

There are various explanations for the contradictory results of the recent literature: the different studies refer to different country samples and time intervals: GGW and RHMBO consider annual data between 1970 and 1999, while LYS focus on the years 1974 to 2000. Conversely, Aghion et al. (2006) consider five-year averages between 1960 and 2000. In addition, LYS use a larger number of countries than RHMBO and GGW. The studies also differ in their choice of control variables that are used to mitigate omitted-variable-bias. Finally, the different analyses use different estimators: while most of the results of GGW and LYS are based on simple OLS-regressions, RHMBO exploit the panel structure of the data set and use a „fixed-effects“-estimator, while Aghion et al. (2006) choose a dynamic panel (GMM) estimator. Concerning the classification methods, it is quite obvious that the different approaches - the use of official announcements (GGW), an endogenous classification by means of cluster analysis (LYS), or a classification based on the observed volatility of (parallel) exchange rates (RR) - lead to different results. The strategy of RR to assign highinflation periods to a separate „freely falling“ category may be another reason why the findings of RHMBO differ from those of LYS.

Given all those differences, it is hard to assess whether the studies' contradictory results convey any insights beyond the trivial statement that distinct methodological choices result in different empirical conclusions. By using a common data set, model specification, and estimation method we eliminate the technical and methodological differences between the three studies, and we hope to get closer to the economic core of their findings.

\section{Exchange rate regimes and growth: data and estimation}

Most of our results are based on estimating the following equation for annual observations between 1974 and 1999: 


$$
\text { Growth }_{i t}=\gamma_{\text {peg }} \text { Dum }_{-} \text {peg }_{i t}^{j}+\gamma_{\text {int }} \text { Dum_int }_{i t}^{j}+\sum_{k=0}^{K} \beta_{k} x_{k, i t}+\xi_{t}+\varepsilon_{i t}
$$

In (1), Growth it $_{\text {is }}$ the growth rate of real per-capita income of country $i$ in year $t$, Dum peg $_{i t}^{j}$ and Dum_int ${ }_{i t}^{j}$ with $j \in\left\{G G W, L Y S, R R^{\bmod }\right\}$ are the dummy variables for pegs and intermediate regimes, as described in the preceding section. Hence, the dummies' coefficients represent the performance of exchange rate regimes relative to a pure float, which is the omitted category. The variables $x_{k, i t}$ are the control variables listed below, and $\xi_{\mathrm{t}}$ is a time dummy which captures world-wide variations in growth rates. We make no assumption on the homoskedasticity and serial correlation of $\varepsilon_{\mathrm{i}}$, and the t-statistics we present are based on a „cluster-robust“ covariance matrix.

While the use of annual data in a growth regression is not above all criticism, we choose this frequency to make our results comparable with those of GGW, LYS, and RHMBO. Concerning the choice of control variables, we closely follow the preceding studies and use a specification that allows to replicate their „benchmark results“. The following variables enter the vector $x$ : The share of investment in GDP (invest), a measure of openness to international trade (open), the change of the terms of trade during the preceding three years (terms-of-trade), the average school enrolment rate (schooling), the government's budget surplus as a share of GDP, lagged by one period (budget_1), the log of the country's percapita income relative to the USA in 1970 (income_ini), the population growth rate (pop_growth), the logarithm of the population size (log_pop), the Freedom House measure of the repression of civil liberties (civil_repress), and dummies for transition countries (dum_trans), oil-rich countries (dum_oil), countries in Sub-Saharan Africa (reg_ssa), and countries in Latin America. (reg_lac). ${ }^{8}$

\section{Exchange rate regimes and growth: Results}

\subsection{Results for the complete sample}

\subsubsection{Three-way classifications}

The results in Table 1 are based on estimating equation (1) by OLS. Column (1.1) uses the dummies for pegs and intermediate regimes based on GGW, column (1.2) refers to the threeway classification of LYS, column (1.3) refers to the (modified) $\mathrm{RR}^{\text {mod }}$-classification. The coefficients of the control variables, while not of crucial interest, have the expected signs, and

\footnotetext{
${ }^{8}$ Detailed information on the definition and sources of control variables are given in the data appendix.
} 
most of them are significant. ${ }^{9}$ Concerning the signs of the regime dummies, we generally replicate the results of the studies introduced above: when we use the de-jure classification of GGW (column 1.1), pegs and intermediate regimes seem to be superior to a floating exchange rate. The opposite holds if the de-facto classification of LYS is used (column 1.2): the variables Dum_peg and Dum_int have negative signs and are statistically significant. The defacto-classification of $\mathrm{RR}^{\text {mod }}$ (column 1.3) yields results which are similar to those in column 1.1, and suggest that a stable exchange rate has a positive effect on economic growth. This finding differs from the results of RHMBO. Recall, however, that we are using a modified version of the original RR classification which does not single out "freely-falling” episodes.

\subsubsection{Four-way classifications and flexibility index}

If we use the four-way classification described in section 2.4 , we are estimating a slightly modified version of equation (1):

$$
\text { Growth }_{i t}=\gamma_{\text {peg }} \text { Dum_peg } \text { pit }^{j}+\gamma_{\text {lim }} \text { Dum_lim }{ }_{i t}^{j}+\gamma_{\text {man }} \text { Dum_man }_{i t}^{j}+\sum_{k=0}^{K} \beta_{k} x_{k, i t}+\xi_{t}+\varepsilon_{i t}
$$

where Dum_lim and Dum_man represent episodes characterized by „limited flexibility“ and „managed floating“, respectively, and „pure float“ is, again, the omitted category. The results of estimating (2) by OLS are reported in columns 2.1 to 2.3 of Table 2 and confirm the results of Table 1: According to the classifications of GGW and $\mathrm{RR}^{\bmod }$, pegs perform better than floats, the coefficients of the LYS dummies suggest the opposite.

An alternative to using binary dummy variables is to construct a „flexibility index“ whose value increases as we move from pegs to floats. ${ }^{10}$ Based on the four-way classification, this variable has the value of one in case of a peg, two if a country has a regime with „limited flexibility“ etc. When we use this flexibility index, our results do not differ substantially from

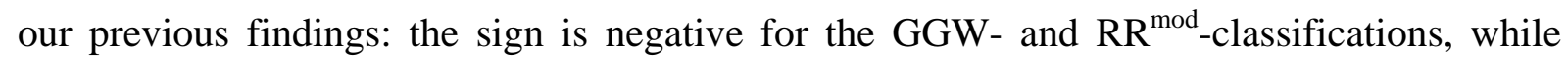
exchange rate flexibility has a positive (though not significant) influence on growth if the LYS-classification is used (see columns 2.4 to 2.6 in Table 2). ${ }^{11}$ We conjecture that the low tstatistic of the flexibility index à la LYS is due to the imposition of a linear relationship which is not justified by the dummies’ coefficients (see column 2.2 in Table 2).

\footnotetext{
${ }^{9}$ To save space, the tables do not include the coefficients of the period dummies, which, by and large, reflect the evolution of the global business cycle - in particular the recession of the early 1980s and the boom of the mid1990s.

${ }^{10}$ This approach is chosen by Aghion et al. (2006).

${ }^{11}$ While our previous results did not hinge on assigning freely-falling episodes to exchange rate regimes - i.e. on using the modified RR-classification ( $\mathrm{RR}^{\mathrm{mod}}$ ) - the coefficient of the RR-flexibility index turned positive, but insignificant, when we omitted freely-falling episodes.
} 


\subsubsection{Alternative estimation methods}

Two econometric problems make it hard to interpret the results presented so far: it is possible that the estimated coefficients merely reflect the influence of country-specific characteristics which are correlated with the regressors but are not explicitly included in the equation. The risk of such an "omitted variable bias" is particularly high in cross-country samples, which are characterized by an enormous degree of unobserved heterogeneity. In addition, the strong correlations we reported in the preceding sections need not indicate causal relationships. Especially when it comes to the de-facto classifications, it is possible that exchange rate stability is both a cause and a consequence of economic growth. If this were indeed the case, the de-facto exchange rate regime would be an endogenous variable, and the results presented above would have to be interpreted with extreme caution.

An appropriate method to acount for unobserved heterogeneity and to reduce omitted variable bias is to use a „fixed effects“ estimator, which essentially introduces a set of dummy variables that capture country-specific, but time-invariant characteristics. Columns 3.1 to 3.3 . in Table 3 present the results of applying this estimator, using the different four-way classifications. Apparently, the GGW-dummies are no longer significant, and some of the coefficients have their signs reversed. The dummies from the LYS-classification keep their signs, but the coefficient of the peg-dummy is no longer significant. Conversely, the coefficients based on the $\mathrm{RR}^{\mathrm{mod}}$-classification confirm the results presented in Table 2 and suggest that higher exchange rate flexibility is associated with lower growth. To explain the poor performance of the GGW dummies, one has to take into account a crucial property of the fixed effects estimator: while reducing the effect of unobserved heterogeneity, this estimator transforms both the dependent variable and the regressors into deviations from countryspecific means, and thus essentially switches off the cross-sectional dimension of the data. Hence, while reflecting the importance of country-specific factors for the choice of exchange rate regimes, the low t-statistics are also due to the low time-variation of the (GGW) regime dummies.

The problem of potential endogeneity can be met by using an instrumental variables (IV) estimator. This estimator replaces potentially endogenous variables with the fitted values of a regression where those variables are regressed on a set of exogenous factors (“instruments"). ${ }^{12}$ These instruments should be correlated with the endogenous variables, but not with the disturbance $\varepsilon$. To instrument for our flexibility index, we use the following

\footnotetext{
${ }^{12}$ Since disturbances are likely to be heteroskedastic, it is preferable to use a GMM estimator. Baum et al. (2003) offer a concise survey on the relevant techniques.
} 
variables $^{13}$ : country size in square kilometres (area), the geographical concentration of exports (xport3), a dummy for a high share of non-fuel raw materials in exports (exp_nonfuel), the Freedom House measure of political repression (pol_repress), and the frequency at which the head of the central bank was replaced in the preceding five years (cbturn5). Columns 3.4 and 3.5 in Table 3 demonstrate that the qualitative effect of the exchange rate regime does not disappear if we use GMM instead of OLS estimation. ${ }^{14}$

\subsubsection{The role of the parallel market}

By and large, the results presented so far replicate the contradictions described in the opening sections: if exchange rate regimes are classified according to LYS, floats appear more advantageous than pegs, if the classifications of GGW or $\mathrm{RR}^{\mathrm{mod}}$ are used, the data suggest the opposite. The discrepancy between LYS and $\mathrm{RR}^{\mathrm{mod}}$ is particularly surprising since both methods claim to provide a de-facto classification of exchange rate regimes.

One reason for this striking difference could be that LYS focus on the official exchange rate, while RR use parallel exchange rates to classify the de-facto exchange rate regime. In developing countries, a stable exchange rate is often associated with a considerable misalignment, and this gives rise to an active parallel market. It is thus conceivable that the negative coefficient of the peg dummy according to LYS does not prove the advantages of exchange rate flexibility, but the growth-depressing distortions that are associated with a severe exchange rate misalignment. To check whether this suspicion gets empirical support, we use the parallel market premium (parallel_premium) - i.e. the markup of the parallel exchange rate over the official rate - as an additional regressor in equation (1). The results in Table 4 demonstrate that this variable has the expected negative sign. However, instead of weakening our previous findings, it reinforces them. It is thus unlikely that the LYS result merely reflects the distortionary effects of persistent exchange rate misalignments.

\subsection{Different country groups}

\subsubsection{Industrial vs. Non-industrial countries}

Both GGW, LYS and RHMBO discuss the possibility that the effects of exchange rate regimes differ across country groups and therefore run their regressions for different samples. In this subsection we follow the approach of LYS and divide our sample into “industrial” and

\footnotetext{
${ }^{13}$ Using the flexibility index instead of regime dummies substantially facilitates IV estimation.

${ }^{14}$ Note, however, that the p-value of Hansen's J-statistic, which is a test of overidentifying restrictions, barely prevents us from rejecting the null hypothesis that our instruments are exogenous.
} 
“non-industrial” economies. ${ }^{15}$ The results for both groups are presented in Table $5 .{ }^{16}$ Rows 5.1 to 5.3 demonstrate that the qualitative discrepancies between the different classifications vanish almost entirely when the analysis is restricted to industrial countries: for this group, all classifications clearly document a better performance of flexible regimes. Conversely, the results for non-industrial countries (rows 5.4 to 5.6) replicate the difference between the three classification methods, although the coefficient of the LYS peg dummy is not significant. ${ }^{17}$ This suggests that the different results on the growth effects of exchange rate regimes in the complete sample are mainly driven by the group of non-industrial countries.

\subsubsection{Advanced countries /emerging markets / developing countries}

An alternative decomposition of the complete sample is suggested by RHMBO: They distinguish (high-income) „advanced countries“, „emerging markets“, which are covered by the Morgan Stanley MSCI-Index, and “developing countries” which belong to neither of the two previous groups. ${ }^{18}$ While this distinction is not above all criticism - it might, for example, be debated whether Bahrain and the Bahamas belong into the same group as France and the USA - it has the advantage of singling out the group of emerging market countries where a combination of high capital mobility and weak institutions raises the vulnerability for financial crises. Rows 5.7 to 5.15 in Table 5 essentially confirm the impression we got when using the industrial/non-industrial decomposition: for the rich economies, we get an almost unanimous verdict that exchange rate flexibility enhances growth (rows 5.7 to 5.9). For the emerging markets, by contrast, the classifications of GGW and $R^{\text {mod }}$ emphasize the advantages of a stable exchange rate, while LYS suggest that flexible regimes have a positive (though not significant) effect on growth rates (rows 5.10 to 5.12). Surprisingly, only the $\mathrm{RR}^{\text {mod }}$-classification suggests that the exchange rate regime has any growth effects in the remaining group of “developing countries” (rows 5.13 to 5.15).

\subsection{The role of high inflation rates and currency crises}

\subsubsection{High inflation rates}

As detailed in Section 2.4, the preceding results have been based on a modified RR classification $\left(\mathrm{RR}^{\mathrm{mod}}\right)$, which assigns all "freely falling” episodes to an exchange rate regime

\footnotetext{
${ }^{15}$ The composition of these groups is given in the data appendix.

${ }^{16}$ The coefficients of the control variables are suppressed to save space, but are available on request.

${ }^{17}$ This sheds a dubious light on the robustness of the LYS-results, since Levy-Yeyati and Sturzenegger (2003) emphasize the importance of exchange rate flexibility for non-industrial countries. Edwards and Levy-Yeyati (2005) argue that this is due to a flexible exchange rate's greater ability to absorb real (terms of trade) shocks.

${ }^{18}$ The composition of these groups is given in the data appendix.
} 
instead of treating them as a separate category. In this section, we explore the importance of this modification and the role of high inflation rates. We proceed in two ways: first, "freely falling episodes" are set equal to zero in all three classifications. ${ }^{19}$ Alternatively, a "freelyfalling dummy” is used as a separate regressor.

The consequences of „neutralizing“ the freely-falling episodes for all regime classifications are displayed in rows 6.1 to 6.3 of Table 6 . The only contrast to the previous results is that the coefficient of the peg-dummy à la LYS now indicates a significantly positive effect of fixed exchange rates. This suggests that the superiority of floats in previous regressions was driven by a number of episodes which LYS classified as de-facto pegs, and which were characterized by high inflation and low growth rates. ${ }^{20}$

When we return to the original classifications but introduce a freely-falling dummy (dum_FF), the changes are more dramatic (see rows 6.4 to 6.6 in Table 6): while the coefficient of the freely-falling dummy is negative and highly significant, the regime dummies per se do not seem to be very important. This suggests the following interpretation: the superior growth performance of pegs à la GGW and $\mathrm{RR}^{\mathrm{mod}}$ that was documented by our previous regressions apparently resulted from the fact that de-jure and de-facto exchange rate stability reduce the likelihood of very high inflation rates. ${ }^{21}$ Once these high-inflation episodes are captured by a separate control variable, the exchange rate regime is no longer important. Note that this does not imply that the choice of exchange rate regime is generally irrelevant: first, very high inflation rates are usually observed in developing countries and emerging markets, such that the negative growth effect of pegs we found for the group of industrial countries is likely to survive an explicit consideration of freely-falling episodes. ${ }^{22}$ Second, in looking at the low t-statistics in Table 6, we must not forget the influence of the exchange rate regime on the likelihood of high inflation rates. Hence, even if the direct growth effect of a fixed exchange rate is small once high inflation episodes are controlled for, the indirect effect may be substantial.

\footnotetext{
${ }^{19}$ For the RR-classification, this means that, instead of assigning freely-falling episodes to a de-facto exchange rate regime, we are using the original regime dummies of Reinhart and Rogoff (2004), which are set to zero in freely-falling episodes. To highlight this difference, we label column 6.3 as referring to RR.

${ }^{20}$ This conjecture is supported by Aghion et al. (2006:23) who find that the difference between exchange rate volatility à la LYS and exchange rate volatility à la RR/GGW disappears once freely-falling episodes are eliminated and periods with dual exchange rates are reclassified according to RR.

${ }^{21}$ When we used the non-modified RR-classification in which freely-falling episodes are set equal to zero, we got the same result, i.e. the regime dummies turned insignificant once dum_FF was introduced as a separate regressor.

${ }^{22} \mathrm{~A}$ regression that exclusively focuses on industrial countries supports this conjecture.
} 


\subsubsection{Currency crises}

The results presented in the previous subsection suggest that our initial findings were driven by a number of „exceptional episodes“. Apart from considering the high-inflation years identified by RR, it is therefore worth wile to isolate country-years characterized by currency crises. Rows 6.7 to 6.9 in Table 6 present the results we got when we omitted currency-crises episodes from our sample. ${ }^{23}$ Interestingly, this modification hardly has an effect on the signs and significance of the regime dummies according to GGW and LYS. However, the superior growh performance of pegs à la $\mathrm{RR}^{\text {mod }}$ disappears almost completely. This indicates that the preference for de-facto exchange rate stability suggested by the $\mathrm{RR}^{\text {mod }}$-classification is due to the serious recessions which, during currency crises, are associated with strong exchange rate volatility. $^{24}$

\section{4. "Fear of floating“ and „Fear of pegging“}

In our previous estimations, we separately considered the classifications of GGW, LYS and $\mathrm{RR}^{\mathrm{mod}}$. As mentioned above, these classifications reflect different aspects of exchange rate policy: GGW focus on official announcements (“words”), LYS on active exchange rate stabilization (“deeds”), and $\mathrm{RR}^{\mathrm{mod}}$ on the resulting volatility of the relevant exchange rate (“outcomes”). In this section, we explore whether the discrepancy between words, deeds, and outcomes has an influence on economic growth which goes beyond the effect of the officially announced regime. ${ }^{25}$ Does the "fear of floating" (Calvo and Reinhart, 2002) enhance growth, i.e. is it recommended to implicitly stabilize the exchange rate instead of officially announcing a peg? Are there benefits of allowing the exchange rate to be more volatile than would be justified by the official regime - a strategy labeled "fear of pegging" by Alesina and Wagner (2006)?

To answer these questions, we proceed as follows: In addition to the GGW regime dummies we use a dummy „Dum_FoF“ which is one if the de-facto regime is more rigid than the de-jure regime, i.e. if we observe "fear of floating”. Conversely, the dummy "Dum_FoP" is one whenever the de-facto regime is more flexible than the de-jure regime, i.e. if there is a

\footnotetext{
${ }^{23}$ To identify currency crises, we used an index provided by GGW, which is based on Glick and Hutchison (1999).

${ }^{24}$ When we followed Aghion et al. (2006) by adding a currency-crisis dummy instead of omitting these episodes the results presented in the preceding sections did not change.

${ }^{25}$ Genberg und Swoboda (2005) argue that the effects of announcements may differ from those of actual policies. Dubas et al. (2005) explore the consequences of "words" deviating from "deeds" for economic growth. However, they limit their attention to their own „effective“ regime classification and only distinguish between fixed and flexible exchange rates.
} 
"fear of pegging". Since we consider two de-facto classifications, we compute these dummies for both the LYS and the $\mathrm{RR}^{\mathrm{mod}}$-classification.

Table 7 presents the results. Column 7.1 refers to the entire sample and shows that a strategy of implicitly stabilizing the exchange rate reduces growth if the de-facto classification of LYS is used. The FoP-dummy is not significant. Column 7.2 shows that, for the complete sample, discrepancies between de-jure and de-facto regimes à la $\mathrm{RR}^{\mathrm{mod}}$ have no significant effect on growth. As before, there are marked differences if we differentiate between industrial and non-industrial countries: the significant effect of the FoF- and FoPdummmies disappears in the industrial-countries subsample if we use the de-facto classification of LYS (column 7.3) while the $\mathrm{RR}^{\mathrm{mod}}$-classification reveals a significantly negative effect of a "fear of floating" and a positive effect of a "fear of pegging" (column 7.4). If we focus on non-industrial countries, the LYS-classification suggests a negative effect of an implicit exchange rate stabilization (column 7.5). By contrast, this strategy is associated with higher growth rates if the de-facto exchange rate regime is identified à la $\mathrm{RR}^{\text {mod }}$ (column 7.6).

We believe that both the coincidences and the differences reported above illustrate the different aspects of exchange rate policy that are captured by the classifications of LYS and $\mathrm{RR}^{\text {mod: }}$ apparently, industrial countries benefit in terms of a better growth performance if the exchange rate fluctuates stronger than suggested by the officially announced regime, i.e. if monetary authorities allow the exchange rate to absorb macroeconomic shocks without jeopardizing the credibility conveyed by a de-jure peg. Conversely, a strategy of implicit exchange rate stabilization - i.e. a "fear of floating" - seems to result in higher growth when non-industrial are considered: due to weak financial institutions, widespread liability dollarization and an exposure to sudden stops, depreciations of the domestic currency are often contractionary in these countries (Calvo, 2005), and limiting exchange rate fluctuations may contribute to macroeconomic stability. The contrast between the negative coefficient of the FoP-dummy à la LYS and the positive coefficient for the FoP-dummy à la $\mathrm{RR}^{\text {mod }}$ indicates that we need to qualify this statement: an implicit exchange rate stabilization seems to be counterproductive if it is enforced by means of heavy foreign exchange intervention. By contrast, if exchange rate stability reflects a stable macroeconomic environment as well as a transparent and consistent monetary policy, the "fear of floating” yields the expected benefits. 


\section{Concluding remarks}

Our goal was to shed some light on the confusing variety of results concerning the relationship between exchange rate regimes and economic growth. We tried to figure out to which extent these contradictory results provide economic insights that go beyond technical and methodological differences, and started from the simple diagnosis that the different studies use classification methods which emphasize different aspects of exchange rate stability - the signaling function of official announcements (GGW), the combination of exchange rate stability and reserves volatility characterizing an active exchange rate stabilization (LYS), or the de-facto fluctuations of the "relevant" exchange rate (RR). Our analysis was driven by the notion that the different results on the exchange-rate regime/growth relationship reveal which of these aspects have a positive or negative effect on growth. Based on these considerations, we summarize our main results.

Our estimates show that the various classification methods yield fairly similar results if attention is restricted to industrial countries: for this group, exchange rate flexibility is associated with higher growth rates. Conversely, we find strong differences between the individual classifications if we consider the subsample of ("non-industrial”) developing countries and emerging markets. In these countries, both the announcement of a peg (GGW) and de-facto stability of the (parallel) exchange rate (RR) have a positive impact on growth. However, the results we got when we used the de-facto classification of LYS suggest that the relationship turns negative if exchange rate stability is due to heavy intervention in foreign exchange markets.

Our study also demonstrates that the strong results are essentially driven by a (large) number of high-inflation episodes. If we explicitly control for the occurrence of high inflation rates, the exchange rate regime does not seem to have a direct effect on economic growth. However, this finding should not mask the important indirect effects of the exchange rate regime, in particular the negative influence of a peg on the likelihood of high inflation.

When it comes to exploring the consequences of "fear of floating" and "fear of pegging”, it is once more important to differentiate between industrial and non-industrial countries: industrial countries seem to benefit from allowing exchange rate fluctuations that occur in the shadow of a rigid official regime. In non-industrial countries, by contrast, a strategy of implicit exchange rate stabilization seems to yield higher growth, unless it is associated with strong fluctuations of foreign reserves and heavy foreign exchange intervention. 
While we believe that our study has clarified a number of important issues, we are realistic about the size of the unexplained rest. In particular, we have completely neglected the dynamic effects of exchange rate policy. Static regressions which search for a relationship between the exchange rate regime and economic growth in the same period do not take into account that the growth effects of a given regime may only materialize if this regime has proven to be sufficiently stable. The relationship between words, deeds, and outcomes may thus be much more complex than suggested by the findings we presented in this study. We believe that this provides ample scope for future research.

\section{References}

Aghion, P., P. Bacchetta, R. Ranciere and K.S. Rogoff (2006): "Exchange Rate Volatility and Productivity Growth: The Role of Financial Development”, NBER Working Paper \# 12117.

Alesina, A. and A.F. Wagner (2006):"Choosing (and Reneging on) Exchange Rate Regimes”, Journal of the EEA 4, 770-799.

Baum, C.F., M.E. Schaffer, and S. Stillman (2003): „Instrumental Variables and GMM: Estimation and Testing“, Boston College Working Paper \# 545.

Baxter, M. and A.C. Stockman (1986): "Business Cycles and the Exchange-Rate Regime Some International Evidence”, Journal of Monetary Economics 23, 377-400.

Bruno, M. and E. William (1998): "Inflation crises and long-run growth", Journal of Monetary Economics 41. 3-26.

Calvo, G. (2005): Emerging Capital Markets in Turmoil - Bad Luck or Bad Policy?, Cambridge MA (MIT Press).

Calvo, G. and C. Reinhart (2002): „Fear of Floating”, Quarterly Journal of Economics 107, 379-408.

Dubas, J.M., B-J. Lee and N.C. Mark (2005): “Effective Exchange Rate Classifications and Growth”, NBER Working Paper \# 11272.

Easterly, W. (2001): The Elusive Quest For Growth, Cambridge MA (MIT Press).

Edwards, S. and E. Levy-Yeyati (2005): “Flexible Exchange Rates as Shock Absorbers”, European Economic Review 49, 2079-2105.

Eichengreen, B. (1994): International Monetary Arrangements for the $21^{\text {st }}$ Century, Washington (Brookings Institution).

Fischer, S. (2001): “Exchange Rate Regimes: Is the Bipolar View Correct?”, Journal of Economic Perspectives 15 (spring), 3-24. 
Genberg, H. and A.K. Swoboda (2005): „Exchange Rate Regimes: Does What Countries Say Matter?“, IMF Staff Papers 52, 129-141.

Glick, R. and M. Hutchison (1999): „Banking and Currency Crises: How Common Are Twins?”, Mimeo.

Gosh, A.R., A-M. Gulde, and H.C. Wolf (2002): Exchange Rate Regimes - Choices and Consequences, Cambridge MA (MIT Press).

Husain, A., A. Mody, and K.S. Rogoff (2005): "Exchange Rate Regime Durability and Performance in Developing vs. Advanced Economies”, Journal of Monetary Economics 52, 35-64.

Levy-Yeyati, E. and F. Sturzenegger (2003): „To Float or to Fix: Evidence on the Impact of Exchange Rate Regimes on Growth”, American Economic Review 93, 1173-1193.

Levy-Yeyati, E. and F. Sturzenegger (2005): „Classifying Exchange Rate Regimes: Deeds vs. Words”, European Economic Review 49, 1603-1635.

Mussa, M. (1986): "Nominal Exchange Rates and the Behavior of Real Exchange Rates Evidence and Implications”, Carnegie-Rochester Conference Series on Public Policy 25, 117214.

Reinhart, C. and K. Rogoff (2004): „The Modern History of Exchange Rate Arrangements: A Reinterpretation“, Quarterly Journal of Economics 119, 1-48.

Rogoff, K., A. Husain, A. Mody, R. Brooks and N. Oomes (2003): „Evolution and Performance of Exchange Rate Regimes”, IMF Working Paper \#243. 


\section{Tables}

Table 1: Regressions using the 3-way classifications

\begin{tabular}{|c|c|c|c|}
\hline & 1.1: GGW & 1.2: LYS & 1.3: $\mathbf{R R}^{\mathrm{mod}}$ \\
\hline Dum_peg & $\begin{array}{c}1.043 \\
(2.09)^{* *}\end{array}$ & $\begin{array}{c}-0.719 \\
(1.88)^{*}\end{array}$ & $\begin{array}{c}1.533 \\
(2.24)^{* *}\end{array}$ \\
\hline Dum_int & $\begin{array}{c}0.934 \\
(2.12)^{* *}\end{array}$ & $\begin{array}{c}-1.629 \\
(3.66)^{* * *}\end{array}$ & $\begin{array}{c}1.932 \\
(3.02)^{* * *}\end{array}$ \\
\hline Invest & $\begin{array}{c}0.094 \\
(2.95)^{* * *}\end{array}$ & $\begin{array}{l}0.055 \\
(1.61)\end{array}$ & $\begin{array}{c}0.082 \\
(2.41)^{* *}\end{array}$ \\
\hline Open & $\begin{array}{l}0.005 \\
(0.63)\end{array}$ & $\begin{array}{l}0.010 \\
(1.40)\end{array}$ & $\begin{array}{c}0.012 \\
(2.21)^{* *}\end{array}$ \\
\hline terms of trade & $\begin{array}{c}0.069 \\
(1.88)^{*}\end{array}$ & $\begin{array}{c}0.093 \\
(2.16)^{* *}\end{array}$ & $\begin{array}{c}0.091 \\
(2.39)^{* *}\end{array}$ \\
\hline schooling & $\begin{array}{c}0.003 \\
(2.11)^{* *}\end{array}$ & $\begin{array}{c}0.002 \\
(1.65)\end{array}$ & $\begin{array}{c}0.003 \\
(2.17)^{* *}\end{array}$ \\
\hline budget_1 & $\begin{array}{l}-0.166 \\
(1.43)\end{array}$ & $\begin{array}{l}-0.148 \\
(1.44)\end{array}$ & $\begin{array}{c}-0.212 \\
(1.96)^{*}\end{array}$ \\
\hline income_ini & $\begin{array}{c}-1.186 \\
(3.16)^{* * *}\end{array}$ & $\begin{array}{c}-1.121 \\
(2.73)^{* * *}\end{array}$ & $\begin{array}{c}-1.240 \\
(3.20)^{* * *}\end{array}$ \\
\hline pop_growth & $\begin{array}{c}-1.120 \\
(3.90)^{* * *}\end{array}$ & $\begin{array}{c}-1.307 \\
(3.74)^{* * *}\end{array}$ & $\begin{array}{c}-1.184 \\
(4.37)^{* * *}\end{array}$ \\
\hline log_pop & $\begin{array}{l}-0.060 \\
(0.29)\end{array}$ & $\begin{array}{l}-0.244 \\
(1.17)\end{array}$ & $\begin{array}{l}0.134 \\
(0.80)\end{array}$ \\
\hline civil_repress & $\begin{array}{l}0.067 \\
(0.49)\end{array}$ & $\begin{array}{l}0.309 \\
(1.65)\end{array}$ & $\begin{array}{l}0.030 \\
(0.19)\end{array}$ \\
\hline reg_ssa & $\begin{array}{c}-1.230 \\
(1.98)^{* *}\end{array}$ & $\begin{array}{c}-1.684 \\
(2.76)^{* * *}\end{array}$ & $\begin{array}{l}-0.229 \\
(0.39)\end{array}$ \\
\hline reg_lac & $\begin{array}{l}-0.409 \\
(0.97)\end{array}$ & $\begin{array}{l}-0.576 \\
(1.26)\end{array}$ & $\begin{array}{l}0.250 \\
(0.61)\end{array}$ \\
\hline dum_trans & $\begin{array}{c}-5.003 \\
(4.16)^{* * *}\end{array}$ & $\begin{array}{c}-4.011 \\
(3.54)^{* * *}\end{array}$ & $\begin{array}{c}-5.291 \\
(3.88)^{* * *}\end{array}$ \\
\hline dum_oil & $\begin{array}{l}0.769 \\
(0.69)\end{array}$ & $\begin{array}{l}1.694 \\
(1.35)\end{array}$ & $\begin{array}{l}1.157 \\
(1.04)\end{array}$ \\
\hline Constant & $\begin{array}{l}1.422 \\
(0.68)\end{array}$ & $\begin{array}{c}6.294 \\
(2.96)^{* * *}\end{array}$ & $\begin{array}{l}0.241 \\
(0.14)\end{array}$ \\
\hline $\begin{array}{l}\text { Observations } \\
\text { R-squared }\end{array}$ & $\begin{array}{l}2532 \\
0.24\end{array}$ & $\begin{array}{l}2111 \\
0.29\end{array}$ & $\begin{array}{l}2186 \\
0.31\end{array}$ \\
\hline
\end{tabular}

Comments on Table 1: t-statistics in parentheses are based on a cluster-robust covariance matrix. Significance levels: * 10\%, ** 5\%, Niveau; *** 1\%. GGW refers to the de-jure classification of Gosh, Gulde and Wolf (2002), LYS to the de-facto classification of Levy-Yeyati and Sturzenegger (2003), RR ${ }^{\text {mod }}$ to the modified classification of Reinhart and Rogoff (2004), with “freely-falling” episodes being assigned to exchange rate regimes (see Section 2.4). 
Table 2: Regressions using the 4-way classification and the flexibility-index

\begin{tabular}{|c|c|c|c|c|c|c|}
\hline & 2.1: GGW & 2.2: LYS & 2.3: $\mathbf{R R}^{\mathrm{mod}}$ & 2.4: GGW & 2.5: LYS & 2.6: $\mathbf{R R}^{\mathrm{mod}}$ \\
\hline Dum_peg & $\begin{array}{c}1.060 \\
(2.09)^{* *}\end{array}$ & $\begin{array}{c}-0.726 \\
(1.90)^{*}\end{array}$ & $\begin{array}{c}1.551 \\
(2.25)^{* *}\end{array}$ & & & \\
\hline Dum_lim & $\begin{array}{l}0.761 \\
(1.36)\end{array}$ & $\begin{array}{c}-1.296 \\
(3.33)^{* * *}\end{array}$ & $\begin{array}{c}2.241 \\
(3.02)^{* * *}\end{array}$ & & & \\
\hline Dum_man & $\begin{array}{c}1.081 \\
(2.05)^{* *}\end{array}$ & $\begin{array}{c}-2.007 \\
(3.13)^{* * *}\end{array}$ & $\begin{array}{c}1.669 \\
(2.54)^{* *}\end{array}$ & & & \\
\hline Flexibility index & & & & $\begin{array}{c}-0.276 \\
(1.84)^{*}\end{array}$ & $\begin{array}{l}0.145 \\
(1.17)\end{array}$ & $\begin{array}{c}-0.325 \\
(1.80)^{*}\end{array}$ \\
\hline invest & $\begin{array}{c}0.094 \\
(2.93)^{* * *}\end{array}$ & $\begin{array}{l}0.055 \\
(1.61)\end{array}$ & $\begin{array}{c}0.082 \\
(2.44)^{* *}\end{array}$ & $\begin{array}{c}0.096 \\
(2.98)^{* * *}\end{array}$ & $\begin{array}{c}0.057 \\
(1.68)^{*}\end{array}$ & $\begin{array}{c}0.090 \\
(2.62)^{* *}\end{array}$ \\
\hline open & $\begin{array}{l}0.005 \\
(0.63)\end{array}$ & $\begin{array}{l}0.010 \\
(1.39)\end{array}$ & $\begin{array}{c}0.012 \\
(2.10)^{* *}\end{array}$ & $\begin{array}{l}0.005 \\
(0.66)\end{array}$ & $\begin{array}{l}0.009 \\
(1.25)\end{array}$ & $\begin{array}{c}0.012 \\
(1.99)^{* *}\end{array}$ \\
\hline terms of trade & $\begin{array}{c}0.069 \\
(1.88)^{*}\end{array}$ & $\begin{array}{c}0.093 \\
(2.17)^{* *}\end{array}$ & $\begin{array}{c}0.089 \\
(2.42)^{* *}\end{array}$ & $\begin{array}{c}0.068 \\
(1.88)^{*}\end{array}$ & $\begin{array}{c}0.093 \\
(2.15)^{* *}\end{array}$ & $\begin{array}{c}0.087 \\
(2.27)^{* *}\end{array}$ \\
\hline schooling & $\begin{array}{c}0.003 \\
(2.04)^{* *}\end{array}$ & $\begin{array}{l}0.002 \\
(1.64)\end{array}$ & $\begin{array}{c}0.003 \\
(2.32)^{* *}\end{array}$ & $\begin{array}{c}0.003 \\
(2.03)^{* *}\end{array}$ & $\begin{array}{c}0.002 \\
(1.66)^{*}\end{array}$ & $\begin{array}{c}0.003 \\
(2.10)^{* *}\end{array}$ \\
\hline budget_1 & $\begin{array}{l}-0.166 \\
(1.43)\end{array}$ & $\begin{array}{l}-0.149 \\
(1.45)\end{array}$ & $\begin{array}{c}-0.215 \\
(1.97)^{*}\end{array}$ & $\begin{array}{l}-0.165 \\
(1.42)\end{array}$ & $\begin{array}{l}-0.145 \\
(1.40)\end{array}$ & $\begin{array}{c}-0.207 \\
(1.89)^{*}\end{array}$ \\
\hline income_ini & $\begin{array}{c}-1.152 \\
(2.86)^{* * *}\end{array}$ & $\begin{array}{c}-1.102 \\
(2.67)^{* * *}\end{array}$ & $\begin{array}{c}-1.245 \\
(3.26)^{* * *}\end{array}$ & $\begin{array}{c}-1.206 \\
(3.29)^{* * *}\end{array}$ & $\begin{array}{c}-1.083 \\
(2.56)^{* *}\end{array}$ & $\begin{array}{c}-1.313 \\
(3.40)^{* * *}\end{array}$ \\
\hline pop_growth & $\begin{array}{c}-1.122 \\
(3.88)^{* * *}\end{array}$ & $\begin{array}{c}-1.306 \\
(3.74)^{* * *}\end{array}$ & $\begin{array}{c}-1.176 \\
(4.40)^{* * *}\end{array}$ & $\begin{array}{c}-1.126 \\
(3.97)^{* * *}\end{array}$ & $\begin{array}{c}-1.305 \\
(3.74)^{* * *}\end{array}$ & $\begin{array}{c}-1.191 \\
(4.35)^{* * *}\end{array}$ \\
\hline log_pop & $\begin{array}{l}-0.060 \\
(0.30)\end{array}$ & $\begin{array}{l}-0.247 \\
(1.18)\end{array}$ & $\begin{array}{l}0.136 \\
(0.82)\end{array}$ & $\begin{array}{l}-0.044 \\
(0.21)\end{array}$ & $\begin{array}{l}-0.270 \\
(1.28)\end{array}$ & $\begin{array}{l}0.080 \\
(0.49)\end{array}$ \\
\hline civil_repress & $\begin{array}{l}0.061 \\
(0.46)\end{array}$ & $\begin{array}{c}0.312 \\
(1.67)^{*}\end{array}$ & $\begin{array}{l}0.045 \\
(0.29)\end{array}$ & $\begin{array}{l}0.066 \\
(0.47)\end{array}$ & $\begin{array}{l}0.299 \\
(1.61)\end{array}$ & $\begin{array}{l}0.031 \\
(0.19)\end{array}$ \\
\hline reg_ssa & $\begin{array}{c}-1.216 \\
(1.98)^{* *}\end{array}$ & $\begin{array}{c}-1.672 \\
(2.74)^{* * *}\end{array}$ & $\begin{array}{l}-0.107 \\
(0.17)\end{array}$ & $\begin{array}{c}-1.342 \\
(2.10)^{* *}\end{array}$ & $\begin{array}{c}-1.614 \\
(2.58)^{* *}\end{array}$ & $\begin{array}{l}-0.668 \\
(1.11)\end{array}$ \\
\hline reg_lac & $\begin{array}{l}-0.419 \\
(0.98)\end{array}$ & $\begin{array}{l}-0.594 \\
(1.30)\end{array}$ & $\begin{array}{l}0.327 \\
(0.76)\end{array}$ & $\begin{array}{l}-0.397 \\
(0.92)\end{array}$ & $\begin{array}{l}-0.696 \\
(1.54)\end{array}$ & $\begin{array}{l}0.044 \\
(0.10)\end{array}$ \\
\hline dum_trans & $\begin{array}{c}-5.013 \\
(4.17)^{* * *}\end{array}$ & $\begin{array}{c}-3.986 \\
(3.55)^{* * *}\end{array}$ & $\begin{array}{c}-5.148 \\
(3.83)^{* * *}\end{array}$ & $\begin{array}{c}-4.984 \\
(4.12)^{* * *}\end{array}$ & $\begin{array}{c}-4.113 \\
(3.62)^{* * *}\end{array}$ & $\begin{array}{c}-5.269 \\
(3.67)^{* * *}\end{array}$ \\
\hline dum_oil & $\begin{array}{l}0.724 \\
(0.67)\end{array}$ & $\begin{array}{l}1.688 \\
(1.35)\end{array}$ & $\begin{array}{l}1.286 \\
(1.10)\end{array}$ & $\begin{array}{l}0.799 \\
(0.71)\end{array}$ & $\begin{array}{l}1.605 \\
(1.28)\end{array}$ & $\begin{array}{l}1.468 \\
(1.28)\end{array}$ \\
\hline Constant & $\begin{array}{l}1.373 \\
(0.66)\end{array}$ & $\begin{array}{c}6.256 \\
(2.93)^{* * *}\end{array}$ & $\begin{array}{l}0.065 \\
(0.04)\end{array}$ & $\begin{array}{l}2.821 \\
(1.48)\end{array}$ & $\begin{array}{c}5.406 \\
(2.48)^{* *}\end{array}$ & $\begin{array}{c}3.043 \\
(1.76)^{*}\end{array}$ \\
\hline $\begin{array}{l}\text { Observations } \\
\text { R-squared }\end{array}$ & $\begin{array}{l}2532 \\
0.24\end{array}$ & $\begin{array}{l}2111 \\
0.30\end{array}$ & $\begin{array}{c}2186 \\
0.31\end{array}$ & $\begin{array}{l}2532 \\
0.24\end{array}$ & $\begin{array}{l}2111 \\
0.29\end{array}$ & $\begin{array}{l}2186 \\
0.30\end{array}$ \\
\hline
\end{tabular}

Comments on Table 2: see Table 1 
Table 3: Fixed effects and GMM-estimations

\begin{tabular}{|c|c|c|c|c|c|}
\hline & 3.1: GGW & 3.2: LYS & 3.3: $\mathbf{R R}^{\mathrm{mod}}$ & 3.4: LYS & 3.5: $\mathbf{R R}^{\mathrm{mod}}$ \\
\hline Dum_peg & $\begin{array}{l}-0.343 \\
(0.63)\end{array}$ & $\begin{array}{c}-0.318 \\
(0.67)\end{array}$ & $\begin{array}{c}2.701 \\
(3.23)^{* * *}\end{array}$ & & \\
\hline Dum_lim & $\begin{array}{l}0.219 \\
(0.36)\end{array}$ & $\begin{array}{c}-0.932 \\
(2.35)^{* *}\end{array}$ & $\begin{array}{c}2.886 \\
(3.38)^{* * *}\end{array}$ & & \\
\hline Dum_man & $\begin{array}{l}-0.125 \\
(0.26)\end{array}$ & $\begin{array}{c}-1.610 \\
(2.72)^{* * *}\end{array}$ & $\begin{array}{c}2.405 \\
(2.79)^{* * *}\end{array}$ & & \\
\hline Flexibility index & & & & $\begin{array}{c}2.536 \\
(1.87)^{*}\end{array}$ & $\begin{array}{c}-2.337 \\
(2.84)^{* * *}\end{array}$ \\
\hline invest & $\begin{array}{c}0.116 \\
(2.81)^{* * *}\end{array}$ & $\begin{array}{c}0.060 \\
(1.90)^{*}\end{array}$ & $\begin{array}{c}0.081 \\
(2.60)^{* *}\end{array}$ & $\begin{array}{l}0.043 \\
(1.42)\end{array}$ & $\begin{array}{c}0.106 \\
(3.99)^{* * *}\end{array}$ \\
\hline open & $\begin{array}{l}-0.019 \\
(1.09)\end{array}$ & $\begin{array}{l}0.000 \\
(0.03)\end{array}$ & $\begin{array}{l}-0.001 \\
(0.06)\end{array}$ & $\begin{array}{c}0.016 \\
(3.16)^{* * *}\end{array}$ & $\begin{array}{l}0.003 \\
(0.57)\end{array}$ \\
\hline terms of trade & $\begin{array}{c}0.058 \\
(2.02)^{* *}\end{array}$ & $\begin{array}{c}0.081 \\
(2.55)^{* *}\end{array}$ & $\begin{array}{c}0.082 \\
(2.75)^{* * *}\end{array}$ & $\begin{array}{c}0.107 \\
(2.95)^{* * *}\end{array}$ & $\begin{array}{c}0.061 \\
(1.83)^{*}\end{array}$ \\
\hline schooling & $\begin{array}{l}0.009 \\
(1.20)\end{array}$ & $\begin{array}{l}0.009 \\
(1.03)\end{array}$ & $\begin{array}{l}0.010 \\
(1.22)\end{array}$ & $\begin{array}{l}0.002 \\
(1.38)\end{array}$ & $\begin{array}{c}0.004 \\
(2.91)^{* * *}\end{array}$ \\
\hline budget_1 & $\begin{array}{c}-0.241 \\
(1.97)^{*}\end{array}$ & $\begin{array}{c}-0.217 \\
(2.11)^{* *}\end{array}$ & $\begin{array}{c}-0.299 \\
(2.81)^{* * *}\end{array}$ & $\begin{array}{l}-0.157 \\
(1.72)^{*}\end{array}$ & $\begin{array}{c}-0.201 \\
(2.50)^{* *}\end{array}$ \\
\hline income_ini & & & & $\begin{array}{c}-1.281 \\
(2.71)^{* * *}\end{array}$ & $\begin{array}{c}-1.080 \\
(3.31)^{* * *}\end{array}$ \\
\hline pop_growth & $\begin{array}{c}-1.156 \\
(4.43)^{* * *}\end{array}$ & $\begin{array}{c}-1.353 \\
(4.17)^{* * *}\end{array}$ & $\begin{array}{c}-1.177 \\
(4.89)^{* * *}\end{array}$ & $\begin{array}{c}-1.218 \\
(3.45)^{* * *}\end{array}$ & $\begin{array}{c}-0.826 \\
(2.19)^{* *}\end{array}$ \\
\hline log_pop & $\begin{array}{c}-4.831 \\
(2.10)^{* *}\end{array}$ & $\begin{array}{l}-1.699 \\
(0.90)\end{array}$ & $\begin{array}{l}-3.679 \\
(1.62)\end{array}$ & $\begin{array}{c}-0.887 \\
(1.81)^{*}\end{array}$ & $\begin{array}{c}0.328 \\
(2.64)^{* * *}\end{array}$ \\
\hline civil_repress & $\begin{array}{l}-0.243 \\
(1.14)\end{array}$ & $\begin{array}{l}0.180 \\
(0.87)\end{array}$ & $\begin{array}{c}-0.422 \\
(1.87)^{*}\end{array}$ & $\begin{array}{c}0.545 \\
(2.81)^{* * *}\end{array}$ & $\begin{array}{l}0.063 \\
(0.40)\end{array}$ \\
\hline reg_ssa & & & & $\begin{array}{c}-1.495 \\
(2.21)^{* *}\end{array}$ & $\begin{array}{l}0.713 \\
(0.92)\end{array}$ \\
\hline reg_lac & & & & $\begin{array}{c}-1.162 \\
(2.00)^{* *}\end{array}$ & $\begin{array}{l}0.419 \\
(1.04)\end{array}$ \\
\hline dum_trans & & & & $\begin{array}{c}-3.571 \\
(2.54)^{* *}\end{array}$ & $\begin{array}{l}-1.173 \\
(1.15)\end{array}$ \\
\hline dum_oil & & & & $\begin{array}{c}3.301 \\
(2.31)^{* *}\end{array}$ & $\begin{array}{l}1.000 \\
(1.43)\end{array}$ \\
\hline Constant & $\begin{array}{l}9.887 \\
(1.63)\end{array}$ & $\begin{array}{l}3.374 \\
(0.68)\end{array}$ & $\begin{array}{l}4.767 \\
(0.70)\end{array}$ & $\begin{array}{l}-1.287 \\
(0.61)\end{array}$ & $\begin{array}{c}5.386 \\
(2.93)^{* * *}\end{array}$ \\
\hline $\begin{array}{l}\text { Observations } \\
\text { R-squared }\end{array}$ & $\begin{array}{c}2532 \\
0.25\end{array}$ & $\begin{array}{c}2111 \\
0.32\end{array}$ & $\begin{array}{r}2186 \\
033\end{array}$ & 1556 & 1677 \\
\hline $\begin{array}{l}\text { R-squared } \\
\text { Hansen’s J-statistic } \\
\text { (p-value) }\end{array}$ & 0.25 & & & 0.34 & 0.11 \\
\hline
\end{tabular}

Comments on Table 3: See Table 1. Columns 3.1 to 3.3 are based on fixed-effects regressions, columns 3.4 and 3.5 on IV/GMM estimations using the following instruments: area, xport3, exp_nonfuel, pol_repress, cbturn5. 
Table 4: The impact of the parallel market premium

\begin{tabular}{|c|c|c|c|}
\hline & 4.1: GGW & 4.2: LYS & 4.3: $\mathrm{RR}^{\mathrm{mod}}$ \\
\hline Dum_peg & $\begin{array}{c}1.300 \\
(2.35)^{* *}\end{array}$ & $\begin{array}{c}-0.817 \\
(1.91)^{*}\end{array}$ & $\begin{array}{c}1.817 \\
(2.34)^{* *}\end{array}$ \\
\hline Dum_int & $\begin{array}{c}0.977 \\
(2.21)^{* *}\end{array}$ & $\begin{array}{c}-1.915 \\
(3.91)^{* * *}\end{array}$ & $\begin{array}{c}2.118 \\
(3.03)^{* * *}\end{array}$ \\
\hline parallel_premium & $\begin{array}{c}-0.000 \\
(6.41)^{* * *}\end{array}$ & $\begin{array}{c}-0.000 \\
(6.10) * * *\end{array}$ & $\begin{array}{c}-0.035 \\
(1.98)^{*}\end{array}$ \\
\hline invest & $\begin{array}{c}0.092 \\
(2.64)^{* * *}\end{array}$ & $\begin{array}{l}0.056 \\
(1.49)\end{array}$ & $\begin{array}{c}0.091 \\
(2.70)^{* * *}\end{array}$ \\
\hline open & $\begin{array}{l}0.006 \\
(0.72)\end{array}$ & $\begin{array}{c}0.013 \\
(1.86)^{*}\end{array}$ & $\begin{array}{l}0.010 \\
(1.39)\end{array}$ \\
\hline terms of trade & $\begin{array}{c}0.075 \\
(2.07)^{* *}\end{array}$ & $\begin{array}{c}0.095 \\
(2.11)^{* *}\end{array}$ & $\begin{array}{c}0.083 \\
(2.35)^{* *}\end{array}$ \\
\hline schooling & $\begin{array}{c}0.003 \\
(1.98)^{*}\end{array}$ & $\begin{array}{c}0.003 \\
(1.71)^{*}\end{array}$ & $\begin{array}{c}0.003 \\
(1.98)^{*}\end{array}$ \\
\hline budget_1 & $\begin{array}{c}-0.216 \\
(2.05)^{* *}\end{array}$ & $\begin{array}{c}-0.208 \\
(2.15)^{* *}\end{array}$ & $\begin{array}{c}-0.245 \\
(2.49)^{* *}\end{array}$ \\
\hline income_ini & $\begin{array}{c}-0.930 \\
(2.15)^{* *}\end{array}$ & $\begin{array}{c}-0.968 \\
(2.20)^{* *}\end{array}$ & $\begin{array}{c}-0.844 \\
(1.81)^{*}\end{array}$ \\
\hline pop_growth & $\begin{array}{c}-1.193 \\
(3.93)^{* * *}\end{array}$ & $\begin{array}{c}-1.244 \\
(3.31)^{* * *}\end{array}$ & $\begin{array}{c}-1.187 \\
(4.34)^{* * *}\end{array}$ \\
\hline log_pop & $\begin{array}{l}0.062 \\
(0.31)\end{array}$ & $\begin{array}{l}-0.135 \\
(0.61)\end{array}$ & $\begin{array}{l}0.161 \\
(0.81)\end{array}$ \\
\hline civil_repress & $\begin{array}{l}0.241 \\
(1.42)\end{array}$ & $\begin{array}{c}0.389 \\
(1.81)^{*}\end{array}$ & $\begin{array}{l}0.284 \\
(1.54)\end{array}$ \\
\hline reg_ssa & $\begin{array}{c}-1.120 \\
(1.82)^{*}\end{array}$ & $\begin{array}{c}-1.845 \\
(3.22)^{* * *}\end{array}$ & $\begin{array}{l}-0.296 \\
(0.49)\end{array}$ \\
\hline reg_lac & $\begin{array}{l}0.076 \\
(0.16)\end{array}$ & $\begin{array}{l}0.051 \\
(0.10)\end{array}$ & $\begin{array}{l}0.505 \\
(1.05)\end{array}$ \\
\hline dum_trans & $\begin{array}{c}-6.211 \\
(3.89)^{* * *}\end{array}$ & $\begin{array}{c}-5.248 \\
(3.15)^{* * *}\end{array}$ & $\begin{array}{c}-6.210 \\
(3.49)^{* * *}\end{array}$ \\
\hline dum_oil & $\begin{array}{l}0.953 \\
(0.81)\end{array}$ & $\begin{array}{l}1.860 \\
(1.41)\end{array}$ & $\begin{array}{l}1.224 \\
(1.07)\end{array}$ \\
\hline Constant & $\begin{array}{l}1.058 \\
(0.45)\end{array}$ & $\begin{array}{l}0.368 \\
(0.16)\end{array}$ & $\begin{array}{l}-0.866 \\
(0.44)\end{array}$ \\
\hline $\begin{array}{l}\text { Observations } \\
\text { R-squared }\end{array}$ & $\begin{array}{l}1874 \\
0.32\end{array}$ & $\begin{array}{l}1526 \\
0.37\end{array}$ & $\begin{array}{l}1775 \\
0.35\end{array}$ \\
\hline
\end{tabular}

Comments on Table 4: see Table 1 
Table 5: Different country groups

\begin{tabular}{|c|c|c|c|c|c|c|}
\hline & Class. & Countries & Dum_peg & Dum_int & Obs. & R squ. \\
\hline 5.1. & GGW & $\begin{array}{l}\text { Industrial } \\
\text { countries }\end{array}$ & $\begin{array}{l}-0.504 \\
(1.75)^{*}\end{array}$ & $\begin{array}{l}0.042 \\
(0.20)\end{array}$ & 552 & 0.22 \\
\hline 5.2 . & LYS & $\begin{array}{l}\text { Industrial } \\
\text { countries }\end{array}$ & $\begin{array}{l}-0.795 \\
(1.81)^{*}\end{array}$ & $\begin{array}{c}-1.071 \\
(2.16)^{* *}\end{array}$ & 463 & 0.28 \\
\hline 5.3. & $\mathrm{RR}^{\bmod }$ & $\begin{array}{l}\text { Industrial } \\
\text { countries }\end{array}$ & $\begin{array}{c}-1.792 \\
(5.54)^{* * *}\end{array}$ & $\begin{array}{c}-1.168 \\
(4.07)^{* * *}\end{array}$ & 552 & 0.24 \\
\hline 5.4 & GGW & $\begin{array}{l}\text { Non-industrial } \\
\text { countries }\end{array}$ & $\begin{array}{c}1.264 \\
(2.07)^{* *}\end{array}$ & $\begin{array}{c}1.531 \\
(2.49)^{* *}\end{array}$ & 1980 & 0.26 \\
\hline 5.5 & LYS & $\begin{array}{l}\text { Non-industrial } \\
\text { countries }\end{array}$ & $\begin{array}{l}-0.486 \\
(1.06)\end{array}$ & $\begin{array}{c}-1.614 \\
(3.15)^{* * *}\end{array}$ & 1648 & 0.31 \\
\hline 5.6 & $\mathrm{RR}^{\text {mod }}$ & $\begin{array}{l}\text { Non-industrial } \\
\text { countries }\end{array}$ & $\begin{array}{c}3.132 \\
(4.38)^{* * *}\end{array}$ & $\begin{array}{c}3.468 \\
(4.60)^{* * *}\end{array}$ & 1634 & 0.34 \\
\hline 5.7 & GGW & $\begin{array}{l}\text { Advanced } \\
\text { countries }\end{array}$ & $\begin{array}{l}-0.166 \\
(0.28)\end{array}$ & $\begin{array}{l}-0.595 \\
(0.89)\end{array}$ & 709 & 0.64 \\
\hline 5.8 & LYS & $\begin{array}{l}\text { Advanced } \\
\text { countries }\end{array}$ & $\begin{array}{l}-1.084 \\
(1.85)^{*}\end{array}$ & $\begin{array}{c}-1.636 \\
(2.78)^{* * *}\end{array}$ & 562 & 0.78 \\
\hline 5.9 & $\mathrm{RR}^{\text {mod }}$ & $\begin{array}{l}\text { Advanced } \\
\text { countries }\end{array}$ & $\begin{array}{c}-2.728 \\
(2.55)^{* *}\end{array}$ & $\begin{array}{c}-2.028 \\
(2.30)^{* *}\end{array}$ & 685 & 0.66 \\
\hline 5.10 & GGW & $\begin{array}{l}\text { Emerging } \\
\text { markets }\end{array}$ & $\begin{array}{c}2.088 \\
(2.60)^{* *}\end{array}$ & $\begin{array}{c}2.186 \\
(2.63)^{* *}\end{array}$ & 486 & 0.20 \\
\hline 5.11 & LYS & $\begin{array}{l}\text { Emerging } \\
\text { markets }\end{array}$ & $\begin{array}{l}-0.094 \\
(0.13)\end{array}$ & $\begin{array}{c}-2.778 \\
(2.63)^{* *}\end{array}$ & 429 & 0.22 \\
\hline 5.12 & $\mathrm{RR}^{\text {mod }}$ & $\begin{array}{l}\text { Emerging } \\
\text { markets }\end{array}$ & $\begin{array}{c}3.359 \\
(3.50)^{* * *}\end{array}$ & $\begin{array}{c}3.978 \\
(4.47)^{* * *}\end{array}$ & 486 & 0.22 \\
\hline 5.13 & GGW & $\begin{array}{c}\text { Developing } \\
\text { countries }\end{array}$ & $\begin{array}{l}0.178 \\
(0.24)\end{array}$ & $\begin{array}{l}0.243 \\
(0.32)\end{array}$ & 1337 & 0.15 \\
\hline 5.14 & LYS & $\begin{array}{c}\text { Developing } \\
\text { countries }\end{array}$ & $\begin{array}{l}-0.445 \\
(0.98)\end{array}$ & $\begin{array}{l}-0.518 \\
(1.07)\end{array}$ & 1120 & 0.17 \\
\hline 5.15 & $\mathrm{RR}^{\text {mod }}$ & $\begin{array}{c}\text { Developing } \\
\text { countries }\end{array}$ & $\begin{array}{c}1.775 \\
(2.37)^{* *}\end{array}$ & $\begin{array}{c}1.681 \\
(2.00)^{*}\end{array}$ & 1015 & 0.22 \\
\hline
\end{tabular}

Comments on Table 5: see Table 1. To save space, the coefficients and t statistics of the control variables are omitted. 
Table 6: Considering “freely falling” episodes and currency crises

\begin{tabular}{|c|c|c|c|c|c|c|c|}
\hline & Class. & Comment & Dum_peg & Dum_int & Dum_FF & Obs. & R squ. \\
\hline 6.1. & GGW & FF episodes $=0$ & $\begin{array}{c}1.697 \\
(3.50)^{* * *}\end{array}$ & $\begin{array}{c}1.424 \\
(3.38)^{* * *}\end{array}$ & -- & 2540 & 0.25 \\
\hline 6.2 . & LYS & FF episodes $=0$ & $\begin{array}{c}0.782 \\
(2.22)^{* *}\end{array}$ & $\begin{array}{l}0.446 \\
(0.99)\end{array}$ & -- & 2152 & 0.28 \\
\hline 6.3. & RR & FF episodes $=0$ & $\begin{array}{c}1.499 \\
(2.66)^{* * *}\end{array}$ & $\begin{array}{c}2.175 \\
(3.88)^{* * *}\end{array}$ & -- & 2198 & 0.31 \\
\hline 6.4 & GGW & & $\begin{array}{l}0.441 \\
(1.06)\end{array}$ & $\begin{array}{l}0.632 \\
(1.54)\end{array}$ & $\begin{array}{c}-2.876 \\
(4.44)^{* * *}\end{array}$ & 2216 & 0.31 \\
\hline 6.5 & LYS & & $\begin{array}{c}-0.927 \\
(2.24)^{* *}\end{array}$ & $\begin{array}{c}-1.472 \\
(3.27)^{* * *}\end{array}$ & $\begin{array}{c}-2.252 \\
(3.38)^{* * *}\end{array}$ & 1855 & 0.34 \\
\hline 6.6 & $\mathrm{RR}^{\mathrm{mod}}$ & & $\begin{array}{l}0.248 \\
(0.37)\end{array}$ & $\begin{array}{c}1.024 \\
(1.89)^{*}\end{array}$ & $\begin{array}{c}-2.791 \\
(3.74)^{* * *}\end{array}$ & 2186 & 0.32 \\
\hline 6.7 & GGW & No curr. Crises & $\begin{array}{c}0.997 \\
(1.92)^{*}\end{array}$ & $\begin{array}{c}0.858 \\
(1.85)^{*}\end{array}$ & -- & 2287 & 0.26 \\
\hline 6.8 & LYS & No curr. Crises & $\begin{array}{c}-0.884 \\
(1.99)^{* *}\end{array}$ & $\begin{array}{c}-1.526 \\
(3.04)^{* * *}\end{array}$ & -- & 1912 & 0.32 \\
\hline 6.9 & $\mathrm{RR}^{\mathrm{mod}}$ & No curr. Crises & $\begin{array}{l}0.680 \\
(0.96)\end{array}$ & $\begin{array}{c}1.291 \\
(1.96)^{*}\end{array}$ & -- & 1956 & 0.33 \\
\hline
\end{tabular}

Comments on Table 6: see Table 5. In the estimations underlying rows 6.1 to 6.3, regime-dummies were set equal to zero in episodes classified as "freely falling” by Reinhart and Rogoff (2004). For the results reported in rows 6.4 to 6.9 we used the regime dummies of the previous estimations. For row 6.7 to 6.9, we omitted episodes in which, according to GGW, there was a currency crisis. 
Table 7: "Fear of floating" and "Fear of pegging”

\begin{tabular}{|c|c|c|c|c|c|c|}
\hline & 7.1: LYS & 7.2: $\mathbf{R R}^{\mathrm{mod}}$ & $\begin{array}{l}\text { 7.3: LYS } \\
\text { ind }\end{array}$ & $\begin{array}{l}\text { 7.4: } \mathbf{R R}^{\bmod } \\
\text { ind }\end{array}$ & $\begin{array}{l}\text { 7.5: LYS } \\
\text { non-ind }\end{array}$ & $\begin{array}{c}\text { 7.6: } \mathrm{RR}^{\mathrm{mod}} \\
\text { non-ind }\end{array}$ \\
\hline Dum_peg & $\begin{array}{l}0.022 \\
(0.04)\end{array}$ & $\begin{array}{l}0.810 \\
(1.38)\end{array}$ & $\begin{array}{c}-0.844 \\
(2.96)^{* * *}\end{array}$ & $\begin{array}{c}-1.926 \\
(4.32)^{* * *}\end{array}$ & $\begin{array}{c}0.076 \\
(0.11)\end{array}$ & $\begin{array}{c}2.159 \\
(2.92)^{* * *}\end{array}$ \\
\hline Dum_lim & $\begin{array}{l}0.360 \\
(0.57)\end{array}$ & $\begin{array}{l}0.518 \\
(0.76)\end{array}$ & $\begin{array}{l}0.073 \\
(0.27)\end{array}$ & $\begin{array}{c}-0.821 \\
(2.65)^{* *}\end{array}$ & $\begin{array}{l}1.376 \\
(1.36)\end{array}$ & $\begin{array}{c}2.589 \\
(2.64)^{* *}\end{array}$ \\
\hline Dum_man & $\begin{array}{l}0.240 \\
(0.38)\end{array}$ & $\begin{array}{l}0.691 \\
(1.39)\end{array}$ & $\begin{array}{l}-0.361 \\
(0.68)\end{array}$ & $\begin{array}{l}-0.278 \\
(0.74)\end{array}$ & $\begin{array}{l}0.505 \\
(0.71)\end{array}$ & $\begin{array}{c}1.228 \\
(2.00)^{* *}\end{array}$ \\
\hline Dum_FoF & $\begin{array}{c}-0.891 \\
(2.14)^{* *}\end{array}$ & $\begin{array}{l}0.166 \\
(0.38)\end{array}$ & $\begin{array}{l}-0.411 \\
(1.25)\end{array}$ & $\begin{array}{c}-0.739 \\
(3.50)^{* * *}\end{array}$ & $\begin{array}{l}-0.851 \\
(1.77)^{*}\end{array}$ & $\begin{array}{c}1.346 \\
(2.11)^{* *}\end{array}$ \\
\hline Dum_FoP & $\begin{array}{l}-0.011 \\
(0.03)\end{array}$ & $\begin{array}{l}0.160 \\
(0.34)\end{array}$ & $\begin{array}{l}0.295 \\
(0.65)\end{array}$ & $\begin{array}{c}1.301 \\
(4.05)^{* * *}\end{array}$ & $\begin{array}{l}-0.334 \\
(0.69)\end{array}$ & $\begin{array}{l}-0.274 \\
(0.52)\end{array}$ \\
\hline invest & $\begin{array}{l}0.052 \\
(1.52)\end{array}$ & $\begin{array}{c}0.083 \\
(2.47)^{* *}\end{array}$ & $\begin{array}{c}0.077 \\
(2.20)^{* *}\end{array}$ & $\begin{array}{l}0.044 \\
(1.28)\end{array}$ & $\begin{array}{l}0.054 \\
(1.45)\end{array}$ & $\begin{array}{c}0.077 \\
(2.05)^{* *}\end{array}$ \\
\hline open & $\begin{array}{l}0.010 \\
(1.39)\end{array}$ & $\begin{array}{c}0.012 \\
(2.19)^{* *}\end{array}$ & $\begin{array}{l}0.018 \\
(1.60)\end{array}$ & $\begin{array}{c}0.028 \\
(4.11)^{* * *}\end{array}$ & $\begin{array}{l}0.005 \\
(0.58)\end{array}$ & $\begin{array}{l}0.008 \\
(1.05)\end{array}$ \\
\hline \multirow{2}{*}{$\begin{array}{l}\text { terms of } \\
\text { trade }\end{array}$} & 0.094 & 0.088 & -0.057 & -0.008 & 0.096 & 0.087 \\
\hline & $(2.18)^{* *}$ & $(2.32)^{* *}$ & $(2.49)^{* *}$ & $(0.34)$ & $(2.27)^{* *}$ & $(2.34)^{* *}$ \\
\hline schooling & $\begin{array}{c}0.003 \\
(1.84)^{*}\end{array}$ & $\begin{array}{c}0.003 \\
(1.85)^{*}\end{array}$ & $\begin{array}{l}0.001 \\
(1.19)\end{array}$ & $\begin{array}{l}0.001 \\
(0.81)\end{array}$ & $\begin{array}{c}0.003 \\
(1.68)^{*}\end{array}$ & $\begin{array}{l}0.003 \\
(1.60)\end{array}$ \\
\hline budget_1 & $\begin{array}{l}-0.147 \\
(1.44)\end{array}$ & $\begin{array}{c}-0.206 \\
(1.87)^{*}\end{array}$ & $\begin{array}{l}0.033 \\
(0.54)\end{array}$ & $\begin{array}{l}0.001 \\
(0.02)\end{array}$ & $\begin{array}{l}-0.153 \\
(1.51)\end{array}$ & $\begin{array}{l}-0.216 \\
(1.94)^{*}\end{array}$ \\
\hline income_ini & $\begin{array}{c}-1.124 \\
(2.52)^{* *}\end{array}$ & $\begin{array}{c}-1.263 \\
(3.03)^{* * *}\end{array}$ & $\begin{array}{c}-2.660 \\
(3.64)^{* * *}\end{array}$ & $\begin{array}{c}-2.455 \\
(3.51)^{* * *}\end{array}$ & $\begin{array}{l}-0.804 \\
(1.44)\end{array}$ & $\begin{array}{l}-0.686 \\
(1.16)\end{array}$ \\
\hline pop_growth & $\begin{array}{c}-1.307 \\
(3.68)^{* * *}\end{array}$ & $\begin{array}{c}-1.194 \\
(4.25)^{* * *}\end{array}$ & $\begin{array}{c}-0.426 \\
(1.88)^{*}\end{array}$ & $\begin{array}{l}-0.380 \\
(1.72)\end{array}$ & $\begin{array}{c}-1.363 \\
(3.70)^{* * *}\end{array}$ & $\begin{array}{c}-1.268 \\
(4.32)^{* * *}\end{array}$ \\
\hline log_pop & $\begin{array}{l}-0.208 \\
(0.99)\end{array}$ & $\begin{array}{l}0.078 \\
(0.47)\end{array}$ & $\begin{array}{l}0.119 \\
(0.58)\end{array}$ & $\begin{array}{c}0.280 \\
(2.52)^{* *}\end{array}$ & $\begin{array}{l}-0.263 \\
(0.91)\end{array}$ & $\begin{array}{l}0.112 \\
(0.45)\end{array}$ \\
\hline civil_repress & $\begin{array}{l}0.280 \\
(1.57)\end{array}$ & $\begin{array}{l}-0.020 \\
(0.13)\end{array}$ & $\begin{array}{l}-0.410 \\
(1.09)\end{array}$ & $\begin{array}{l}-0.315 \\
(1.30)\end{array}$ & $\begin{array}{l}0.127 \\
(0.75)\end{array}$ & $\begin{array}{l}-0.232 \\
(1.57)\end{array}$ \\
\hline reg_ssa & $\begin{array}{c}-1.506 \\
(2.53)^{* *}\end{array}$ & $\begin{array}{l}-0.538 \\
(0.86)\end{array}$ & & & $\begin{array}{c}-1.712 \\
(2.72)^{* * *}\end{array}$ & $\begin{array}{l}-0.616 \\
(0.92)\end{array}$ \\
\hline reg_lac & $\begin{array}{l}-0.623 \\
(1.37)\end{array}$ & $\begin{array}{l}0.026 \\
(0.06)\end{array}$ & & & $\begin{array}{c}-1.680 \\
(2.55)^{* *}\end{array}$ & $\begin{array}{l}-1.059 \\
(1.45)\end{array}$ \\
\hline dum_trans & $\begin{array}{c}-4.052 \\
(3.12)^{* * *}\end{array}$ & $\begin{array}{c}-5.542 \\
(3.89)^{* * *}\end{array}$ & & & $\begin{array}{c}-5.298 \\
(3.39)^{* * *}\end{array}$ & $\begin{array}{c}-6.936 \\
(4.20)^{* * *}\end{array}$ \\
\hline dum_oil & $\begin{array}{l}1.661 \\
(1.35)\end{array}$ & $\begin{array}{l}1.298 \\
(1.22)\end{array}$ & $\begin{array}{l}0.575 \\
(1.00)\end{array}$ & $\begin{array}{l}-0.434 \\
(0.84)\end{array}$ & $\begin{array}{l}1.282 \\
(1.08)\end{array}$ & $\begin{array}{l}0.681 \\
(0.67)\end{array}$ \\
\hline Constant & $\begin{array}{c}5.521 \\
(2.24)^{* *}\end{array}$ & $\begin{array}{l}1.687 \\
(0.92)\end{array}$ & $\begin{array}{c}9.291 \\
(2.45)^{* *}\end{array}$ & $\begin{array}{c}9.435 \\
(2.89)^{* * *}\end{array}$ & $\begin{array}{c}6.785 \\
(2.50)^{* *}\end{array}$ & $\begin{array}{l}3.124 \\
(1.26)\end{array}$ \\
\hline $\begin{array}{l}\text { Obs. } \\
\text { R-squared }\end{array}$ & $\begin{array}{l}2093 \\
0.29\end{array}$ & $\begin{array}{l}2159 \\
0.30\end{array}$ & $\begin{array}{l}463 \\
0.27\end{array}$ & $\begin{array}{l}552 \\
0.25\end{array}$ & $\begin{array}{l}1630 \\
0.31\end{array}$ & $\begin{array}{l}1607 \\
0.33\end{array}$ \\
\hline
\end{tabular}

Comments on Table 7: see Table 1. Columns 7.1 and 7.2 are based on the entire sample. Columns 7.3 and 7.4 use only "industrial" countries, columns 7.5 and 7.6 only non-industrial countries.

\section{Data Appendix}


Our sample contains data for 167 countries and covers the period from 1974 to 1999. A country is classified as an advanced country if its GNI per capita in the year 2005 was higher than 10726 USD. If a country is included in Morgan Stanley’s MSCI index it is classified as an emerging market. The remaining countries are classified as developing countries.

\section{$\underline{\text { Advanced Countries }}$}

Netherlands Antilles, Australia*, Austria, Belgium, Bahrain, Bahamas, Canada,

Switzerland, Cyprus, Germany, Denmark, Spain, Finland, France, United Kingdom,

Greece, Ireland, Iceland, Italy, Japan, Korea, Kuwait, Luxembourg, Malta, Netherlands,

Norway, New Zealand, Portugal, Qatar, Singapore, Slovenia, Sweden, United Arab

Emirates, United States.

* Countries in bold letters are classified as industrial countries by LYS.

\section{$\underline{\text { Developing Countries }}$}

Afghanistan, Albania, Armenia, Antigua \& Barbuda, Azerbaijan, Burundi, Benin, Burkina Faso, Bangladesh, Bulgaria, Bosnia \& Herzegovina, Belarus, Belize, Bolivia, Barbados, Botswana, Central African Republic, Cote D'Ivoire, Cameroon, Republic of Congo, Comoros, Cape Verde, Costa Rica, Djibouti, Dominica, Dominican Republic, Algeria, Ecuador, Estonia, Ethiopia, Fiji, Gabon, Georgia, Ghana, Guinea, Gambia, Guinea-Bissau, Equatorial Guinea, Grenada, Guatemala, Guyana, Hong Kong, Honduras, Haiti, Iran, Iraq, Jamaica, Kazakhstan, Kenya, Kyrgyz Republic, Lao People's Dem. Rep, Lebanon, Liberia, Libya, St. Lucia, Sri Lanka, Lesotho, Lithuania, Latvia, Moldova, Madagascar, Maldives, Mali, Myanmar, Mozambique, Mauritania, Mauritius, Malawi, Niger, Nigeria, Nicaragua, Nepal, Oman, Panama, Papua New Guinea, Paraguay, Romania, Rwanda, Sudan, Senegal, Solomon Islands, Sierra Leone, El Salvador, Somalia, São Tomé \& Príncipe, Suriname, Slovak Republic, Swaziland, Seychelles, Syrian Arab Republic, Chad, Togo, Tajikistan, Turkmenistan, Tonga, Trinidad \& Tobago, Tunisia, Tanzania, Uganda, Ukraine, Uruguay, Uzbekistan, S.Vincent \& Grenadines, Vietnam, Vanuatu, Samoa, Democratic Republic of Congo, Zambia, Zimbabwe.

\section{Emerging Markets}

Argentina, Brazil, Chile, China (Mainland), Colombia, Czech Republic, Egypt, Hungary, Indonesia, India, Israel, Jordan, Morocco, Mexico, Malaysia, Pakistan, Peru, Philippines, Poland, Russia, Thailand, Turkey, Venezuela, South Africa.

Definitions and sources of variables: 
growth: Annual growth rate of real GDP per capita. Source: Gosh, Gulde and Wolf (2002).

invest: Ratio of gross investments to GDP. Source: Gosh, Gulde and Wolf (2002).

open: Proxy for degree of openness of an economy. Open is the ratio of (Exports + Imports)

to GDP. Source: Gosh, Gulde and Wolf (2002), own calculations.

terms-of-trade: Terms of trade growth rate (3 year backward average). Source: Gosh, Gulde and Wolf (2002).

budget: Ratio of the central government balance to GDP. Source: Gosh, Gulde and Wolf (2002).

schooling: Average years of schooling in the total population over age 25. Source: Gosh, Gulde and Wolf (2002).

income_ini: Logarithm of the ratio of the national GDP per capita to the US per capita GDP in 1970, calculated in international prices. Source: Gosh, Gulde and Wolf (2002).

log_pop: Logarithm of the total population. Source: Gosh, Gulde and Wolf (2002).

pop_growth: Growth rate of the total population. Source: Gosh, Gulde and Wolf (2002).

civil_repress: Index, measuring the degree of civil liberties. The index ranges from 1 (max. freedom) to 7 (min. freedom). Source: Freedom House.

reg_ssa: Regional dummy, equal to 1 if a country is located in Sub Saharan Africa, 0 otherwise. Source: World Bank (2005).

reg_lac: Regional dummy, equal to 1 if a country is located in Latin America, 0 otherwise. Source: World Bank (2005).

dum_trans: Dummy, equal to 1 if a country is characterized as a transition country, 0 otherwise. Source: World Bank (2005).

dum_oil: Oil dummy, equal to 1 for the following countries: Algeria, Indonesia, Iran, Iraq, Kuwait, Libya, Nigeria, Qatar, United Arab Emirates, Venezuela, Russia, Norway, Kazakhstan, 0 otherwise. Source: OPEC, own calculations.

area: country area in square kilometers. Source: World Bank (2005)

xport3: Share of total exports to three largest trading partners. Source: Gosh, Gulde and Wolf (2002).

pol_repress: Index, measuring the extent of political rights. The index ranges from 1 (max. rights) to 7 (min. rights). Source: Freedom House.

cbturn5: Central bank governor turnover rate in the preceding five years. Proxy for central bank independence. Source: Gosh, Gulde and Wolf (2002).

exp_nonfuel: Dummy, equal to 1 if a country is specialized in the export of non-fuel raw materials, 0 otherwise. Source: World Bank (2005). 
parallel_premium: Ratio of parallel market exchange rate over the official exchange rate. Source: Reinhart and Rogoff (2004), own calculations.

dum_crisis: Dummy, equal to 1 if a currency crisis has occured in a country, 0 otherwise. Source: Gosh, Gulde and Wolf (2002), Note: The Gosh, Gulde and Wolf (2002) data based on Glick and Hutchison (1999).

jure_ind4w: Exchange rate regime index. The index ranges from 1 to 4, where 1 equals a Peg, 2 equals Limited flexibility, 3 equals Managed float and 4 equals a Float. The category Peg includes the following IMF subcategories: Dollarization, Currency board, Currency Union, Single currency peg, Published basket peg, and Secret basket peg. The category Limited flexibility includes the subcategories: Cooperative system, Crawling Peg, and Target zone. The category Managed float includes the subcategories: Unclassified rule-based intervention, Managed float with heavy intervention, Unclassified managed float, and Other float. Finally, the category Float includes the subcategories: Float with light intervention and Float with no intervention. Source: Gosh, Gulde and Wolf (2002), own calculations.

jure_ind3w: Exchange rate regime index based on jure_ind4w. The index ranges from 1 to 3 because the categories Limited flexibility and Managed float are combined in the new category Intermediate. Source: Gosh, Gulde and Wolf (2002).

rr_ind4w: De facto exchange rate regime index according to $R^{\bmod }$. The index ranges from 1 to 4, where 1 equals a Peg, 2 equals Limited flexibility, 3 equals Managed float and 4 equals a Float. The category Peg includes the following subcategories: No separate legal tender, Preannounced peg or currency board arrangement, Pre-announced horizontal band that is narrower than or equal to $+/-2 \%$, and de facto peg. The category Limited flexibility includes the subcategories: Pre-announced crawling band, Pre-announced crawling band that is narrower than or equal to $+/-2 \%$, De facto crawling peg, and De facto crawling band that is narrower than or equal to $+/-2 \%$. The category Managed float includes the subcategories: Preannounced crawling band that is wider than $+/-2 \%$, De facto crawling band that is narrower than or equal to $+/-5 \%$, Moving band that is narrower than or equal to $+/-2 \%$ (This definition allows for appreciations and depreciations over time.), and Managed float. The category Float includes the subcategory: Freely Floating. In their original classification, RR use an additional category, Freely falling. This category includes every country-year observation where the annual inflation rate exceeded 40 percent. Using the information in the RR country chronologies, one is able to assign each country-year observation to a de facto exchange rate regime to which it would have belonged, had it not been classified as Freely falling. Source: Reinhart and Rogoff (2004), own calculations. 
rr_ind3w: Exchange rate regime index based on rr_ind4w. The index ranges from 1 to 3, combining the categories Limited flexibility and Managed float in the new category Intermediate. Source: Reinhart and Rogoff (2004), own calculations.

dum_FF: Regime dummy, equal to 1 if a regime is classified as freely falling, 0 otherwise. Source: Own calculations.

lys_ind4w: De facto exchange rate regime index according to LYS. The classification scheme is based on the LYS 5-way classification. We have dropped the category Inconclusives. Hence, the index ranges from 1 to 4, where 1 equals a Peg, 2 equals Limited flexibility (LYS label this category as Dirty/Crawling peg), 3 equals Managed float (LYS label this category as Dirty) and 4 equals a Float. Source: Levy-Yeyati and Sturzenegger (2005), own calculations.

lys_ind3w: Exchange rate regime index based on lys_ind4w. The index ranges from 1 to 3, combining the categories Limited flexibility and Managed float in the new category Intermediate. Source: Levy-Yeyati and Sturzenegger (2005).

dum_z_x: Regime dummy, equal to 1 if the regime „,z“ according to the classification

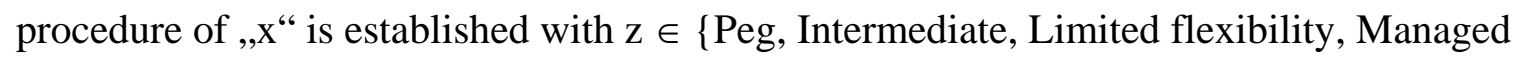
float $\}$ and $x \in\left\{G G W, L Y S, R^{\text {mod }}\right\}$. Source: own calculations.

dum_FoF: Fear of Floating dummy variable, equal to 1 if the de-facto exchange rate regime according to LYS or RR_mod is more restrictive than the de jure exchange rate regime, 0 otherwise. Source: Own calculations based on Alesina and Wagner (2006).

dum_FoP: Fear of Pegging dummy variable, equal to 1 if the de-facto exchange rate regime according to LYS or RR_mod is less restrictive than the de jure exchange rate regime, 0 otherwise. Source: Own calculations based on Alesina and Wagner (2006). 